\title{
Greek and Romance unagreement in Calabria
}

\author{
Georg F.K. Höhn* \\ University of Cambridge/Bergische Universität Wuppertal \\ georg.hoehn.n@alumni.ucl.ac.uk \\ Giuseppina Silvestri \\ University of Cambridge \\ gs486@cam.ac.uk \\ M. Olimpia Squillaci \\ University of Cambridge \\ m.olimpia.squillaci@gmail.com
}

\begin{abstract}
The term 'unagreement' describes configurations with an apparent person-mismatch between a typically definite plural subject and non-third person verbal agreement found in several null subject languages. Previous works have suggested that languages which have an obligatory definite article in adnominal pronoun constructions (APCs) allow unagreement (cf. standard modern Greek emeis oi glossologoi "we (the) linguists"), while languages that rule out definite articles in APCs do not allow unagreement constructions ( $\mathrm{cf}$. standard Italian noi $\left({ }^{*} i\right)$ linguisti). This article presents new evidence from Calabrian Greek (Greko), which corresponds to the predictions for other varieties of Greek, and two southern Italian Romance varieties (northern and southern Calabrese): these varieties exhibit Italian-type APCs but still allow unagreement, contrary to expectations. We discuss how the Romance data may be accommodated by extending a previous account of unagreement and propose that the hybrid pattern observed in the Italo-Romance varieties is a result of historical contact with local Greek varieties.
\end{abstract}

* We thank the reviewers and the editors for their thoughtful comments. Georg Höhn acknowledges funding from the European Research Council Advanced Grant No. $26975^{2}$ "Rethinking Comparative Syntax" for part of this research. Giuseppina Silvestri acknowledges funding from the Leverhulme-funded project "Fading voices in southern Italy: investigating language

(C) G.F.K. HÖHN, G. SILVESTRI AND M.O. SQUILLACI, 2017 | DOI: 10.1163/15699846-01702002

This is an open access article distributed under the terms of the prevailing CC-BY-NC license 


\section{Keywords}

person - adnominal pronouns - pronominal determiners - language contact - ItaloGreek - Italo-Romance

A proper subset of null subject languages (NSLS), including Standard Modern Greek (SMG), Bulgarian, Spanish and Catalan allow definite plural subjects to control not only third, but also first and second verbal person marking as in (1). On a perspective taking definite expressions such as the linguists to be third person, these constructions appear to violate the matching condition on agreement, accounting for the designation of this phenomenon as unagreement (Hurtado 1985). However, not all NSLs allow unagreement, as the ungrammaticality of (2) from standard Italian shows.

(1) Oi glossologoi ekserevnoume ti fysi tis the.NOM.PL linguists investigate.1PL the.ACC.SG nature the.GEN.SG glossas.

language.GEN.SG

'We linguists investigate the nature of language.'

(2) * linguisti studiamo la natura del linguaggio. the.PL linguists investigate.1PL the nature of.the language

[Std. Italian]

In the literature on the issue, two general approaches to the analysis of unagreement can be discerned (for a more detailed overview see Höhn 2016). On the one hand, some authors assume that there is indeed a feature mismatch between the features of the verb and the subject DP in unagreement. Accordingly, this type of approach suggests that the traditional view which considers the subject DP to control the phi-features of verbal inflection is wrong (see e.g. Ackema \& Neeleman 2013), or at least not applicable in these languages and contexts (e.g. Ordóñez \& Treviño 1999; Villa-García 2010). Alternative analyses have instead rejected the notion that the subject DP in unagreement construc-

contact in Magna Graecia”. Maria Olimpia Squillaci acknowledges funding from Trinity College, Cambridge. 
tions is actually third person, arguing that the phi-features expressed in verbal morphology are indeed triggered by grammatical features in the structure of unagreeing subjects (e.g. Choi 2013, 2014; Höhn 2016, 2017).

Both Choi and Höhn suggest that there is a correlation between the availability of unagreement and the requirement for a definite article in adnominal pronoun constructions (APCs)/Pronoun-Noun Constructions (PNCs). ${ }^{1}$ This is illustrated by the contrast between SMG and standard Italian in (3).

(3) a. emeis * (oi) glossologoi

we the.NOM.PL linguists

'we linguists'

b. noi $\left({ }^{*} i\right) \quad$ linguisti

[Std. Italian]

we the.PL linguists

'we linguists'

Choi and Höhn propose the generalisations in (4) and (5) respectively.

(4) PNC pro-drop generalization ( finalversion):

(Choi 2014: 212, (43)) PNC pro-drop [i.e. unagreement; $H S S$ ] is allowed only when

a. the predicate agrees with the PNC in consistent pro-drop languages, AND

b. the PNC contains a definite article.

(5) Null subject languages with definite articles

(Höhn 2016: 56o, (37))

a. show unagreement if they have a definite article in APCs, and

b. do not show unagreement if they have no definite article in APCs.

Both versions are largely equivalent, provided that (5) is understood to refer to consistent NSLS. To the extent that these generalisations are correct, they suggest that the observable crosslinguistic variation of unagreement is dependent on variation in the nominal domain. This supports the view that unagreement itself is an expression of special behaviour of parts of the nominal projection rather than the mechanism of agreement. However, Höhn et al. (2016) present data from two southern Italian varieties of Calabria, northern and southern Calabrese, ${ }^{2}$ which show unagreement while lacking definite arti-

1 We use the term APC throughout this article, except in quotations employing different terminology.

2 We use the names "northern and southern Calabrese" for the two Italian dialects we discuss 
cles in APCs. This calls into question the crosslinguistic generalisations above. Starting therefore from the questions raised in Höhn et al. (2016), in this paper we draw on fresh unpublished data and discuss a new possible analysis for this unexpected unagreement configuration in the Calabrian varieties, which substantially differs from the morphological analysis previously proposed. In particular, in this paper, we discuss the data from these two Italo-Romance varieties in the context of language contact with Greek varieties historically spoken in Calabria and still found in a few villages of the province of Reggio Calabria (southern Calabria). We propose to extend Höhn's (2016) analysis to account for the unexpected availability of unagreement in the Calabrian varieties and offer some discussion of the role of the specific contact situation. The locations of the varieties under discussion here are illustrated in Figure 1.

The data discussed throughout this contribution stem from previous and on-going investigations on properties of the nominal domain for which two of the authors have conducted fieldwork in both areas of northern and southern Calabria; see also Silvestri (2013) and Squillaci (2016). Between 2015 and 2017 both authors, who may also rely on their native competence of the local Greek variety (M.O. Squillaci) as well as the Italo-Romance varieties (G. Silvestri for northern Calabrese, M.O. Squillaci for southern Calabrese) under examination, consulted a number of native speakers of northern and southern Calabrese who belong to older and younger generations in order to corroborate the unagreement patterns in the light of possible variation in more $v s$ less conservative usage. Unless stated otherwise, the Romance and Greek data from Calabria presented in this paper are completely new.

In the next section, we sketch Höhn's (2016) account for unagreement and briefly present two additional subcases of unagreement not discussed in the literature. In section 3, we introduce Calabrian Greek (Greko) and briefly discuss its behaviour with respect to unagreement. Section 4 summarises the problems arising for the generalisations in (4) and (5) from the occurrence of unagreement in northern and southern Calabrese. We propose a potential analysis for the unagreement patterns in the Italo-Romance varieties in section ${ }_{5}$, which we relate to the Greek-Romance contact situation in section 6. Section 7 concludes the paper.

throughout the paper spoken in the Italian region of Calabria in the village of Verbicaro (province of Cosenza, northern Calabria) and Bova Marina (province of Reggio Calabria, southern Calabria), respectively; "Calabrian" here means "spoken in Calabria". 


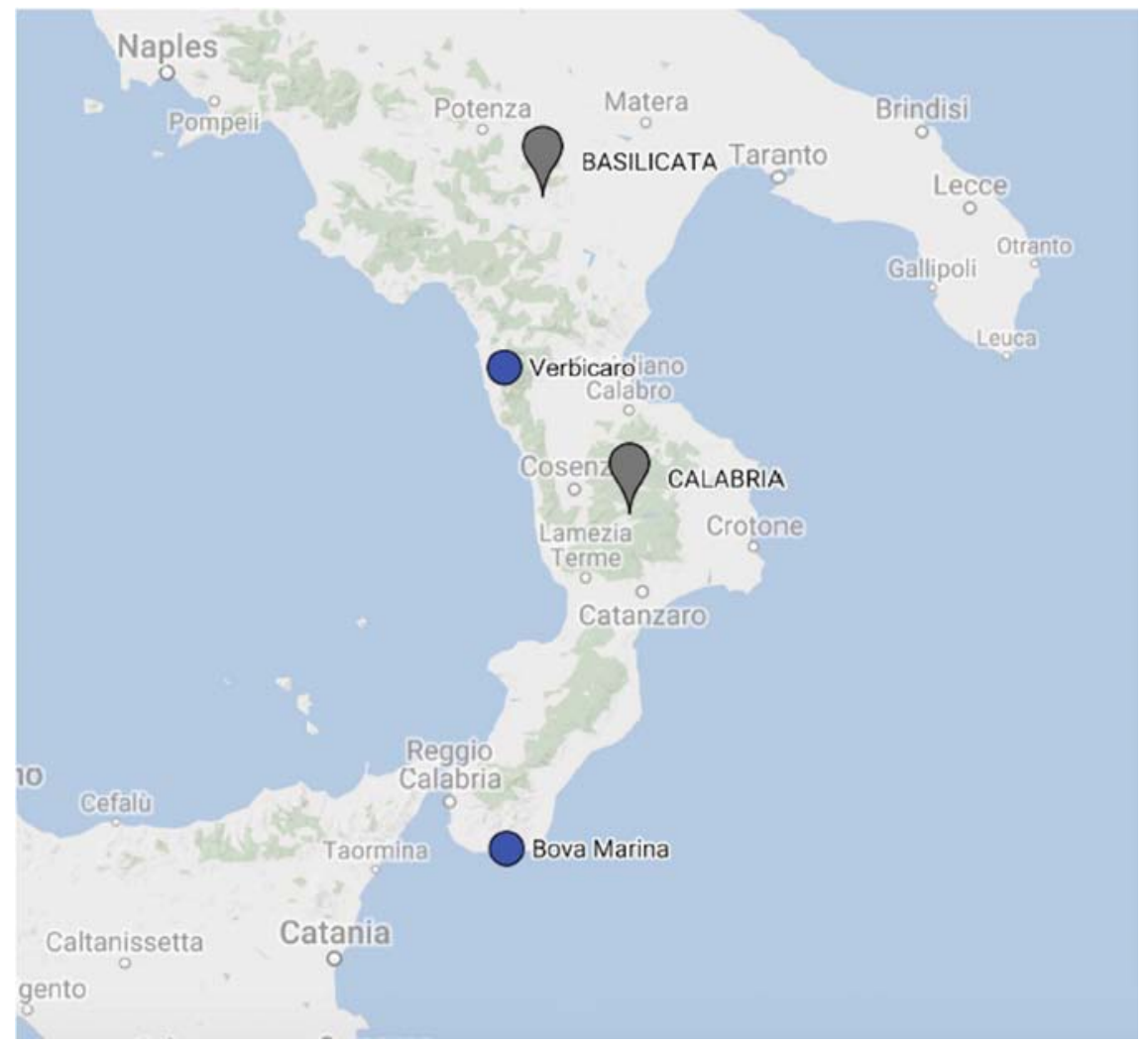

FIGURE 1 The Italian region of Calabria with the villages of Verbicaro, the source of the northern Calabrese data described here, and Bova Marina, the source of the southern Calabrese and Greko data. The region of Basilicata is referenced in section 6.2.

MAP DATA FROM MAPS.GOOGLE.COM

In this section, we summarise Höhn's (2016) account of unagreement, which we are adopting as the basis for our proposals in section 5 and add two subcases of unagreement not discussed in the literature: wh-unagreement and relative clause unagreement. Moreover, we briefly discuss why we chose Höhn (2016) over the competing account by Choi (2013, 2014).

The core of Höhn's (2016) account is that languages with unagreement, like SMG, encode nominal person in a syntactic position distinct from that of the definite article as illustrated in $(6) .^{3}$

3 The practice of decomposing person into two binary features $[ \pm$ part(icipant) $]$ and $[ \pm$ au- 
(6)

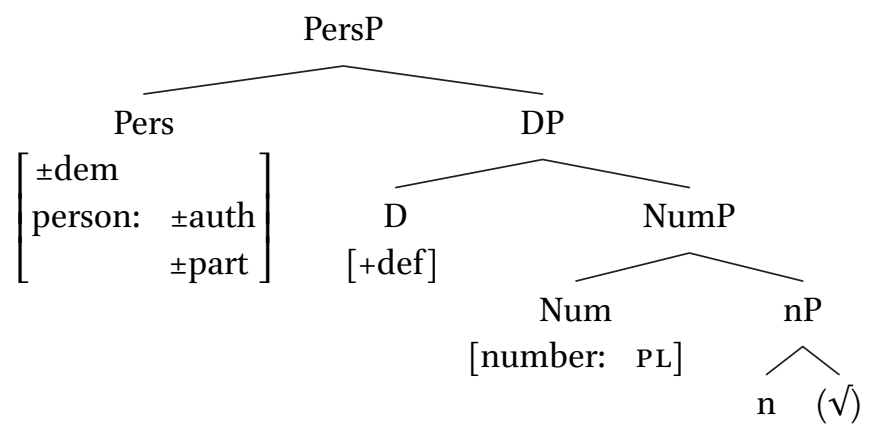

If Pers is spelled out overtly as a personal pronoun according to its feature specification and NumP contains overt material (notably a noun or adjective), the result is an APC. Since Pers and D are distinct heads, this nominal structure will normally show obligatory definite articles in APCs as illustrated for SMG in (3a) above. ${ }^{4}$

Höhn suggests that pronouns have the structure in (6) as well, however with a null nominal element (Panagiotidis 2002) at their core, presumably corresponding to a little $\mathrm{n}$ categoriser without an associated root (Panagiotidis 2011, 2015). The $\mathrm{D}$ head is assumed to receive null spell-out when there is no overt material inside NumP due to the phonologically dependent nature of the article(s), i.e. as a last resort mechanism to avoid stranding the definite article in the absence of an adjective or head noun that could act as a phonological host. For details, see Höhn $(2016,2017)$.

Pro-drop is conceived of as null spell-out of the Pers head carrying person features within such a pronominal structure, yielding a syntactically complex but phonologically unrealised noun phrase in null subject contexts. ${ }^{5}$ When such null spell-out of Pers applies to a structure containing overt material in NumP (notably adjectives or a head noun), the result is unagreement with Pers not overtly realised, while the DP complement remains overt. Recall that languages with unagreement all seem to be null subject languages (Choi 2014, Höhn 2016), so the hypothesis that the same mechanism plays a role in both

th(or)] follows Nevins $(2007,2011)$. [+auth, + part] corresponds to first person in traditional terminology.

4 The counterexamples found in the two Calabrian Romance varieties at the core of this paper are discussed in sections 4-6.

5 Null spell-out of Pers probably needs to be licensed by a probing head identifying the phifeatures on Pers (Höhn 2016:572, fn. 21), typically a T head for subjects and possibly a v head for direct objects (see Höhn 2016:574 ff. for discussion of object unagreement). 
phenomena seems plausible. Adopting the general framework of Distributed Morphology (e.g. Halle \& Marantz 1993; Embick 2010), this insight can be implemented by the vocabulary items (VIs) in (7). Höhn suggests that whether or not Pers is realised overtly depends on the specification of a $[ \pm \mathrm{dem}$ (onstrative)] feature on Pers. Based on the emphatic interpretation triggered by the use of overt pronouns in null subject languages and the parallel behaviour of adnominal pronouns and demonstratives in ruling out unagreement, a [+dem] specification is associated with an overt realisation, while [-dem] Pers heads receive null spell-out as sketched in (7) for SMG. ${ }^{6}$

(7) Pers $[$-dem $] \leftrightarrow \emptyset$
Pers $[+$ dem, + auth, + part, pl $] \leftrightarrow$ emeis

On this account, the main reason that languages like standard Italian do not allow unagreement is that they have actual pronominal determiners (Postal 1969; Abney 1987), i.e. person features are encoded directly on the $\mathrm{D}$ head as sketched in (8).

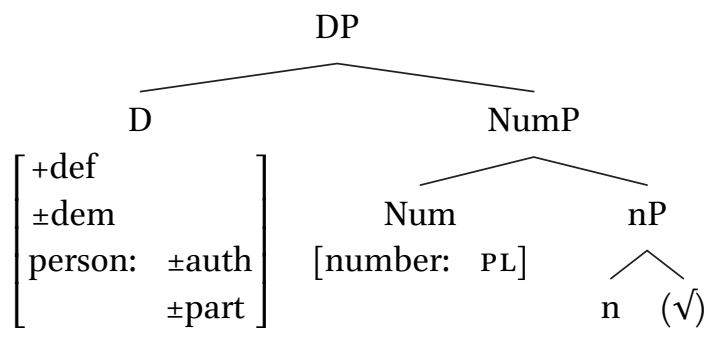

Since person features are encoded directly on $\mathrm{D}$ in this configuration, the realisation of definiteness features and person features is mutually dependent. This means that it is not possible to have null spell-out for person features but not for definiteness. Null spell-out of person features in a structure like (8)

6 The pattern of co-occurrence of definite articles with demonstratives does not seem to be straightforwardly crosslinguistically identical to the pattern of articles in in APCs. Spanish and Bulgarian, for example, require definite articles in APCs but lack definite articles with demonstratives (only for prenominal demonstratives in the case of Spanish). Note, however, that Spanish exhibits an overt definite article with postnominal demonstratives, and colloquial varieties of Bulgarian allow overt definite articles in the presence of demonstratives (Arnaudova 1998 via Caink 2002). This suggests that the co-occurrence patterns of the article with demonstratives and adnominal pronouns may be comparable after all, albeit not identical. 
with an overt lexical noun would result in a bare noun with a definite (and potentially first or second person) interpretation. Importantly, languages like Italian do not allow definite readings of bare nouns (cf. e.g. Longobardi 1994, 2008 among others). Höhn interprets this as a requirement for definiteness to be overtly expressed in the presence of an overt NP. ${ }^{7}$

Choi $(2013,2014)$ also connects the availability of unagreement to the contrast between the presence of definite articles in APCs illustrated in (3) above. In contrast to Höhn's analysis outlined above, however, he proposes that APCS have the same structural configuration in languages with unagreement as in those without. Within a classical DP structure, adnominal pronouns move from a lower specifier position in the extended nominal projection to SpecDP in both types of language as sketched in (9).

(9)

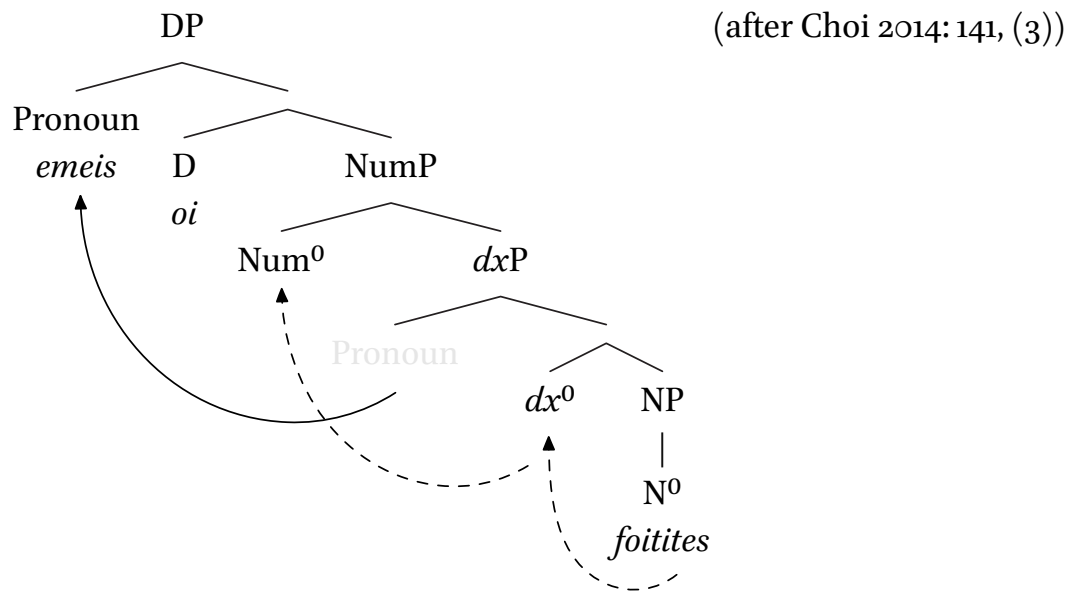

On this analysis, what differentiates languages with unagreement (=PNC prodrop in (4) above) from those without it is the phonological presence of a definite article in APCs. This acts as intermediate licensor for pro-drop applying to the pronoun in SpecDP - see (4b) - in addition to the commonly assumed licensing condition for plain pro-drop, namely (rich) verbal inflection-see (4a).

In contrast, Höhn (2016) argues that the variation in unagreement reflects a structural difference. Höhn's claim that unagreement depends on a structural configuration where person is encoded distinctly from $\mathrm{D}$ is supported by the

7 See Höhn et al. (2016) for an alternative way of deriving unagreement from this structure, which may, however, run into problems with the other types of unagreement discussed below. 
observation of further unagreement-like constructions where D may be either absent altogether or occupied by an element not typically associated with (non-third) person. In the remainder of this section, we sketch three further types of unagreement: quantificational unagreement (see also Ackeman \& Neeleman 2013; Höhn 2016), as well as wh-unagreement and relative clause unagreement, which appear to show similar effects but have not been explicitly discussed in the literature to our knowledge.

The term quantificational unagreement describes instances of non-third person agreement with quantified subject DPs, which typically do not contain overt definite articles, as illustrated for SM G in (10). ${ }^{8}$ The interpretation requires the speaker (first person) or addressee (second person) of the utterance to be a member of the restrictor set of the quantifier, namely neoi 'young people'. Building on Heim (2008) and Höhn (2014a), this effect may be the result of presuppositions triggered by (silent) person features inside the subject phrase. Standard Italian, on the other hand, lacks quantificational unagreement (11), although the language has rich verbal agreement morphology that licenses definite null subjects. This parallels the pattern observed for definite unagreement above.

$$
\begin{aligned}
& \left({ }^{*}\right. \text { Emeis) polloi neoi den echoume douleia. } \\
& \text { we many young.people NEG have.1PL work } \\
& \text { 'Many (of us) young people don't have work.' }
\end{aligned}
$$

\section{(11) ${ }^{*}$ Molti giovani non abbiamo lavoro. many young.people NEG have.1PL Work}

$$
\text { many young.people NEG have.1PL Work }
$$

[Std. Italian]

Choi's account wrongly predicts the Greek sentence in (10) to be ungrammatical because there is no overt article to license PNC pro-drop (alternatively, the phenomenon would have to be treated as unrelated to plain, definite unagreement). This empirical challenge for the view that there is no structural difference between languages with and without unagreement is also relevant to the southern Italo-Romance data presented in section 4.

On the other hand, Höhn's (2016) proposal allows an analysis that captures the variation in quantificational unagreement based on the difference in the structural position of person features (for details see Höhn 2016). In SMG,

8 There appears to be some crosslinguistic variation as to which quantifiers can participate in quantificational unagreement. This is not our focus here; see Höhn (2016) for a comparison of SMG and Spanish. Overt pronouns are not available in such contexts; see below. 
person features are not encoded on definite $\mathrm{D}$ - as shown by the fact that in this language both Pers and $\mathrm{D}$ are reflected in the overt co-occurrence of adnominal pronouns and definite articles in APCs-and are therefore not restricted to definite contexts, though they cannot be overtly realised as personal pronouns in such non-definite contexts. Höhn (2016) connects this to the obligatorily non-demonstrative nature of the relevant contexts. This correspond to the [-dem] feature in (7) above which is associated with null spell-out of Pers. ${ }^{9}$ In contrast, Italian encodes person features on definite $\mathrm{D}$-as reflected by the complementary distribution of adnominal pronouns and definite articles. This prevents the occurrence of person features in non-definite contexts like (11).

In wh-unagreement, an animate wh-subject, arguably indefinite (e.g. Chomsky 1995: 263), controls non-third person verbal agreement; see (12). Like in quantificational unagreement, an overt pronoun is not available here, as expected if overt pronouns require a [+demonstrative] context in line with Höhn's (2016) proposal. The contribution of the person feature in (12) is that the speaker (first person) or addressee (second person) has to be a member of the reference set of every possible answer. Just like quantificational unagreement, wh-unagreement is not available in Italian (13).

(12) (*Emeis) poioi tha pame sto kentro telika? we who.PL FUt go.1PL to.the centre eventually [SMG] 'Who (of us) will go to the centre eventually?'

(13) * Chi andiamo in centro alla fine? [Std. Italian] who.PL go.1PL in centre at.the end

9 Quantifiers without overt articles like polloi "many" may project a QP in the complement of the Pers head: [PersP Pers [QP Q NumP]]. The quantifier oloi "all" would take a full PersP as a complement which in turn contains a DP, since full APCs are possible, e.g. oloi emeis oi glossologoi, lit. all we the linguists, "all us linguists". In support of the proposal that demonstrativity plays a role, note that demonstratives are also possible with this quantifier: oloi aftoi oi glossologoi "all these linguists". The quantifier oi perissoteroi "most" seems to involve the structure [PersP Pers [DP D [QP Q NumP]]] considering the presence of the definite article oi. See also Höhn (2016: 573, fn. 23). Native speakers seem to either reject overt pronouns with this quantifier or at least consider them more marked than regular APCS, which again supports the idea that it is not the presence of the definite article per se that licenses unagreement. For the special behaviour of the distributive quantifier kathe with respect to unagreement, see Höhn (2016:550, fn. 8). 
This contrast follows if languages like Greek merge person features independently of (definite or indefinite) $\mathrm{D}$ in the nominal domain as suggested by Höhn (2016), in the case of (12) scoping over the wh-word inside the same extended nominal projection. If person features are merged on definite $\mathrm{D}$ in Italian, on the other hand, they are correctly predicted to be unavailable in contexts like (13).

Finally, unagreement is also possible in subject relative clauses as in (14). SMG has two types of relative clauses, one introduced by the relative marker pou involving a null subject and one using an overt relative pronoun. Both allow non-third person agreement, although the latter is of more immediate interest to the present discussion, since it involves an overt realisation of the subject and relative pronouns typically exclusively trigger third person agreement in languages without unagreement. The relative pronoun cannot be preceded by an overt pronoun within the subject phrase, which is expected on Höhn's (2016) account on the assumption that relative pronouns cannot be [+demonstrative]. Like the other types of unagreement, this is not possible in standard Italian (15).

(14) Oi foitites $\left\{\left({ }^{*}\right.\right.$ eseis $)$ oi opoioi/ pou $\}$

the.NOM.PL students you.PL the.NOM.PL REL.PL REL

diavasate kserete gia poio pragma milao. read.PST.2PL know.2PL about what thing speak.1SG

'You students who did your readings know what I am talking about.'

(15) * Gli studenti che avete letto sapete di che the.PL students REL.PL have.2PL read. PPT know.2PL of what cosa parlo.

[Std. Italian] thing speak.1SG

To conclude this section, we have seen four types of unagreement constructions: (classic) definite unagreement, quantificational unagreement, wh-unagreement and relative clause unagreement. We take these constructions to have a common structural basis in the dissociation of person features from the D projection in line with Höhn's (2016) proposal.

The next two sections present the unagreement patterns in Calabrian Greek and in northern and southern Calabrese. 
Having outlined our approach to unagreement, we now move on to analyse the varieties under consideration. In this section, we start by presenting data from Calabrian Greek.

Although much research has been carried out on the morpho-syntax of Greko, no previous work has dealt with the unagreement phenomenon in this variety. We argue here that Greko patterns with SMG as far as the availability of unagreement and the structure of APCs is concerned. Consider the example in (16), which shows that definite plural subjects can control not only third person plural agreement, but equally first and second person. ${ }^{10}$

(16) Ta pedia pèzome/pèzete/pèzusi me ta chartia. [Greko] the.PL children play.1PL/2PL/3PL with the.PL cards

'We/you/the children play with cards.'

As in SMG, APCs in Greko obligatorily contain a definite article following the adnominal pronoun, see (17).

(17) Emi* ${ }^{*}$ ta) pedia den pinnome kafè. we the.PL children NEG drink.1PL coffee 'We children don't drink coffee.'

Example (18) shows that the same holds for demonstratives, suggesting again a correlation between APCs and demonstratives.

(18) Tuta *(ta) pedia pau sto spiti. this.PL the.PL children go.3PL to.the house 'These children go home.'

Both adnominal pronouns and demonstratives restrict the availability of unagreement insofar as verbal agreement in examples (17) and (18) is obligatorily first and third person plural respectively.

The data presented above suggest that the unagreement pattern attested in the Greek variety of Calabria is identical to that found in SMG. Additionally, the

10 As stated in the introduction, the data presented and discussed in this paper were collected during numerous fieldwork trips to Calabria by G. Silvestri and M.O. Squillaci between 2014 and 2017. Furthermore, these two authors also relied on their native com- 
data show that Greko has not been influenced in this respect by neighbouring Romance varieties or standard Italian, neither of which manifest unagreement, cf. (2). Importantly, Greko supports Choi's and Höhn's generalisation on the unagreement pattern, since it is a consistent null subject language (cf. Katsoyannou 1995) and it obligatorily exhibits the definite article in APCs, as demonstrated in (17).

Again like SMG, Greko also displays quantificational unagreement as shown in (19).

(19) Liga/ poddà/ ola ta/ pende pedia trògome ode. few many all the.PL five children eat.1PL here 'Few/ many/ all the/ five (of us) children eat in here.'

Calabrian Greek also patterns with SMG with respect to the availability of whand relative clause unagreement, see (20).

(20) ( $\left.{ }^{*} E m i\right)$ pii pame sto Gaddicianò avri?

[Greko] we who.PL go.1PL to.the Gallicianò tomorrow

'Who (of us) will go to Gallicianò tomorrow?'

(21) ta pedia \{( ${ }^{*}$ emi) ti/ pou\} ejàmma eci [Greko] the.NOM.PL children we REL pu.REL go.PST.1PL there 'we children who went there'

To conclude this section, we note that we have not found evidence for morphosyntactic microvariation between SMG and Greko in the domain of nominal person and assume that the analysis outlined above for APCs and unagreement in SMG applies in Greko as well.

\section{$4 \quad$ Unagreement in Calabrian Italo-Romance varieties}

Turning now to the Romance varieties spoken in Calabria, Höhn et al. (2016) observe unagreement data in two southern Italian dialects, namely northern

petence in northern Calabrese and southern Calabrese and Greko respectively. The data reported in the paper reflect their judgments, which were tested and continuously corroborated with $15^{-20}$ native speakers (only around 8 for Greko) between January 2015 and May 2017 in each of the relevant localities (Verbicaro for northern Calabrese and Bova Marina for southern Calabrese and Greko). 
and southern Calabrese, $\mathrm{cf} .(22 \mathrm{~b}-\mathrm{c})$, in contrast to standard Italian as illustrated in (22a). ${ }^{11}$

(22) a. *I bambini giochiamo a carte. the.PL children play.1PL at cards

[Standard Italian]

b. I quatrara iucama $i \quad$ carta. the.PL children play.1PL the.PL cards 'We children play cards.'
c. I figghioli iocamu e carti. [Southern Calabrese] the.PL children play.1PL the.PL cards 'We children play cards.'

On the other hand, however, these two southern Italo-Romance varieties differ from other languages with unagreement, like SMG and Greko, in that they do not allow the definite article in APCs. In this respect, they pattern with standard Italian, as shown in (23).

(23) a. Noi $\left({ }^{*} i\right)$ bambini giochiamo a carte.

[Standard Italian] we the.PL children play.1PL at cards 'We children play cards.'

b. Nua $\left({ }^{*} i\right)$ quatrara iucamə $i \quad$ carta. [Northern Calabrese] we the.PL children play.1PL the.PL cards 'We children play cards.'
c. Nui $\left({ }^{*} i\right) \quad$ figghioli iocamu e carti. [Southern Calabrese] we the.PL children play.1PL the.PL cards 'We children play cards.'

Höhn et al. (2016) notice that these data present a problem for the previously observed correlation between definiteness marking and unagreement (Choi 2013, 2014; Höhn 2016). In particular, the southern Italo-Romance patterns of unagreement contradict the second statement of Höhn's generalisation, as

11 The data in (22) and (23) closely resemble examples (1)-(3) in Höhn et al. (2016:137f.) and Höhn et al. (2016:142, (13)) respectively. 
expressed in $(5 \mathrm{~b})$ and repeated below as $(24 \mathrm{~b})$, as well as Choi's Condition on $\mathrm{D}^{0}$ in (4).

(24) Null subject languages with definite articles

a. show unagreement if they have a definite article in APCs, and

b. do not show unagreement if they have no definite article in APCs.

The observed contrast with standard Italian and the pattern predicted by (24) call for an explanation. Before turning to a potential analysis in the next section, we need to additionally point out that both varieties also exhibit the other types of unagreement introduced in section 2, again in contrast with standard Italian. Quantificational unagreement is illustrated in (25), wh-unagreement in (26) and relative clause unagreement in (27).

(25) a. Abbogghia giughənə non lavurama. [Northern Calabrese] many young.people NEG work.1PL 'Many (of us) young people do not work.'

b. Assai figghioli non lavuramu. many young.people NEG work.1PL 'Many (of us) young people do not work.'

(26) a. $\mathrm{Cu}$ partiaza crai?

[Northern Calabrese] who.PL leave.2PL tomorrow 'Who (of you) will leave tomorrow?'

b. $\mathrm{Cu} \quad$ jiti domani? [Southern Calabrese] who.PL go.2PL tomorrow 'Who (of you) will go tomorrow?'

(27) a. I quatrara kkə jamə a scola scriviamə miagghja the.PL children REL go.1PL to school write.1PL better

[Northern Calabrese]

'We children who go to school (know how to) write better.'

b. I figghioli chi iamu a scola scrivimu megghiu the.PL children REL go.1PL to school write.1PL better

[Southern Calabrese]

'We children who go to school (know how to) write better.' 
As observed in section 2, the standard Italian counterparts of these examples are ungrammatical. The next session discusses the significance of these patterns.

5 Extending the hidden feature analysis

The lack of definite articles in APCs in northern and southern Calabrese observed in the previous section challenges the connection between the presence of definite articles in APCs and the availability of unagreement suggested by Choi's $(2013,2014)$ and Höhn's (2016) generalisations. While it may seem tempting to wholly reject the idea of such a connection on the basis of these problematic data, we think it would be rash to dismiss the still relatively robust-albeit not exceptionless ${ }^{12}$ - correlation observed by Choi and Höhn as accidental. In the absence of a new generalisation, doing so would not only not provide an explanation for the problems raised in the previous section, but it would also negate any insights gained into the wider crosslinguistic distribution of unagreement on the basis of these tendencies.

So instead of rejecting the connection between the structure of APCs and the availability of unagreement, we would like to suggest that the structural configuration Höhn (2016) proposes as the basis of unagreement (see section 2) extends to the southern Italian dialects as well..$^{13}$ On this analysis, person features are encoded separately from D like in SMG and Calabrian Greek, rather than being located on $\mathrm{D}$ as in standard Italian. The relevant structure, which we suggest applies in northern and southern Calabrese as well, is repeated in (28).

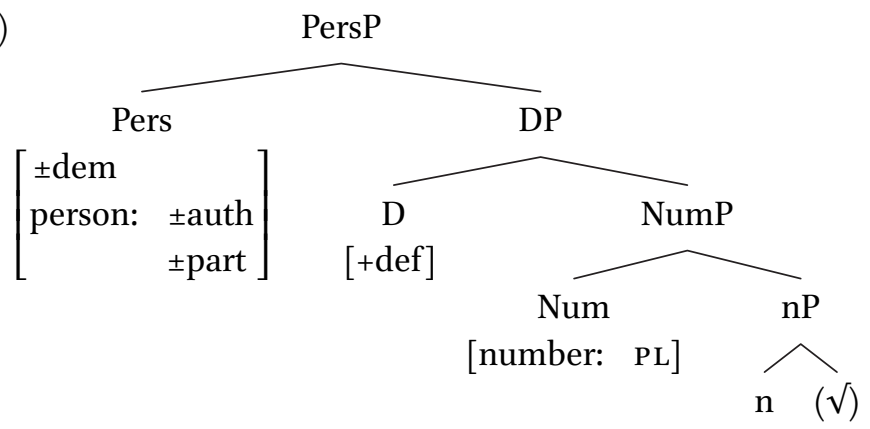

\footnotetext{
12 In addition to the unpredicted availability of unagreement discussed here, Höhn (2016: 560 , fn. 15) mentions the unexpected lack of unagreement in Romanian and some Semitic languages. See Höhn (2017: ch. 6) for further discussion of this aspect.

An alternative account presented by Höhn et al. (2016) assumes that the crucial difference
} 
This means that in contrast to standard Italian, person features and definiteness are encoded on structurally distinct heads. Consequently, the presence of a definite article in a subject does not entail grammatical third person features as it does in standard Italian, since the trigger for-particularly non-thirdperson agreement, the Pers head, is independent from $\mathrm{D}$. Since these languages allow pro-drop, person features may receive null spell-out, which results in the typical unagreement configuration.

Importantly, an approach of this sort retains the idea that there is a structural correlate of unagreement in the guise of the PersP structure, with person and definiteness encoded in separate structural positions. This leads to the prediction mentioned in section 2 that nominal person marking should be able to occur in non-definite contexts in languages with this type of structural independence of person and definiteness (see also Höhn 2017: ch. 4). This is systematically attested in the phenomena of quantificational and wh-unagreement first discussed in section 2. Relative clause unagreement represents a further context indicating a disjunction between person features and definiteness. As shown in section 4, the two Calabrian Romance varieties at issue here do not only differ from standard Italian in allowing classical unagreement with definite plural subjects, but also allow these other types of unagreement. This supports our proposal that person features are represented in a position distinct from $\mathrm{D}$ in these languages as well.

Of course, this analysis raises the question of why APCs in both southern Romance varieties follow the pattern of standard Italian, where the cooccurrence of definite article and adnominal pronoun is excluded, rather than that of the Greek varieties (SMG, Calabrian Greek) with obligatory definite articles in APCs. Assuming an analysis with distinct Pers and D heads, there is no a priori reason why their exponence should be mutually exclusive in the southern Italian varieties. In fact, one would rather expect a replication of the Greek pattern. Note, however, that the presence of an overtly realised definite article itself is not a formal requirement for the licensing of unagreement on Höhn's (2016) analysis that we propose to extend to these cases. Rather, it is the structurally distinct representation of person from $\mathrm{D}$ that is responsible for the availability of definite, quantificational, wh- and relative clause unagreement.

between standard Italian and the southern dialects under discussion is not in their structure, but in the specification of their vocabulary items. While this reduction to the vocabulary is attractive from the perspective of learnability, it offers no principled explanation for the systematic existence of non-definite types of unagreement. For this reason, we prefer the account in the main text as a general account, although a vocabulary-based account may have played a role at some early stage of language contact (see section 6). 
Therefore, we do not take this to be a fatal problem and assume that $\mathrm{D}$ receives null spell-out in the context of an overt Pers head in APCs in these southern Italo-Romance varieties.

We suspect that the unexpected lack of an overt article in APCs may be connected to the particular sociolinguistic and contact situation these varieties find themselves in. An observation bearing on this issue concerns the status of APCS. In languages like SMG, such expressions are regularly available, as shown by the optional presence of the overt pronoun in (29). The same holds for Calabrian Greek, as illustrated in (30).

(29) (Eseis) oi glossologoi mou lete treles istories. [SMG] you.PL the.PL linguists me.GEN tell.2PL crazy stories 'You linguists tell me crazy stories.'

(30) (Esise) $i \quad$ miccedde den troghete poddi. you.PL the.PL girls NEG eat.2PL much 'You girls don't eat much.'

In contrast, reactions from our northern and southern Calabrese informants indicate that in these varieties APCs are perceived as highly marked compared to unagreement constructions, to the extent that some speakers perceive them as instances of code-switching to standard Italian.

The reactions of our informants suggest that APCs are not widely used in these southern Italo-Romance varieties and are therefore presumably also rare in the primary linguistic data at the disposal of children acquiring these varieties. If this is the case, one would not expect them to play an important role in language acquisition. This suggests an interesting switch in perspective regarding the relationship of APCS and unagreement, with potential implications beyond the languages discussed here. Rather than particular APC structures providing the trigger for the acquisition of unagreement, it may be unagreement constructions that provide the relevant cues for the learner to posit a nominal structure with person and definiteness encoded independently of each other. Unfortunately, we are not aware of any corpus or acquisition studies that could clarify the actual distribution of unagreement and APCs in primary linguistic data and their relative accessibility and development in language acquisition. These would be fruitful areas for future research — not only on the internal dialectal variation discussed here, but also more generally. ${ }^{14}$

14 Complications for studies of this sort on Greko and the two Calabrian Italo-Romance 
In any case, the type of APCs with overt definite articles attested in languages like SMG, Calabrian Greek or Spanish would represent the unmarked way of realising such a structure acquired on the basis of unagreement. As stated above, this does not preclude the possibility that the $\mathrm{D}$ head may remain unpronounced under specific circumstances in some languages. Against that background, the complementary distribution of definite articles and adnominal pronouns observed in the southern Italo-Romance varieties discussed here could be due to a surface-oriented constraint against their co-occurrence ${ }^{15}$ rather than an indication that they realise the same syntactic position. Such a constraint may be the result of language contact with standard Italian, leading to a reproduction of the surface representation of standard Italian APCs while still retaining a distinct underlying syntactic structure.

Pushing this analysis, one may consider the possibility that the person head in these varieties can only be realised overtly by a personal pronoun if there is no overt phonological material in its complement domain. Höhn (2017: ch. 2 and 3) describes a similar pattern in Basque, which also rules out adnominal uses of personal pronouns leading to a lack of (straightforward) APCs. On this view, both Calabrian Romance varieties under discussion may also lack APCS altogether. Indeed, it seems that speakers are reluctant to use APCs even in contrastive contexts like (31), which typically help to trigger [+dem] APCS with an overt realisation of Pers in other unagreement languages. In these varieties, consultants appear to much prefer to reformulate APCs in such sentences in terms of plain personal pronouns instead.

(31) YOU troops will remain but the other troops will embark. (Sommerstein 1972: 204)

The observed APC pattern resembling that of standard Italian would seem to only be a last resort, used when the speaker is urged to use an overt pronoun or, e.g., when a nominal expression with non-third person occurs in isolation.

varieties arise from the non-standardised nature of the languages. A further concern for Greko in particular is its endangered status and the very low number of remaining native speakers.

15 The unexpected complementary distribution of two nodes expected to be adjacent may be the result of interaction of contextual restrictions of the vocabulary items involved (for discussion of such an effect in Basque, see Höhn 2014b). In the present cases, it may be that $\mathrm{D}$ receives null spell-out in the local context of a [+dem] Pers head and the overt realisation of Pers is restricted to contexts where it is not followed by an overtly realised D. 
In the latter case, the person of an unagreeing nominal expression (i.e., a phrase looking like a plain definite noun phrase but with non-third person interpretation) cannot be identified due to the lack of an agreeing $\mathrm{T}$ head. Such an unagreement structure with a null Pers head would be indistinguishable from a plain definite noun phrase, for which pragmatic considerations would presumably favour a default third person interpretation. This relates to the additional requirement for a phi-agreeing probe ( $\mathrm{T}$ in the case of unagreeing subjects) to license the null realisation of Pers mentioned in footnote 6 above, which makes identification of the person/number properties of the nominal phrase possible in the absence of overt marking in the nominal phrase. If there is no probe identifying the phi-features of the Pers head, the mutual exclusivity of the overt realisation of either Pers or D seems to exceptionally make way for a realisation of Pers rather than $\mathrm{D}$, leading to a surface string resembling the standard Italian APC pattern (and indeed possibly influenced by it).

The next section considers the appearance of unagreement in the southern Italian varieties under discussion against the background of the language contact situation in which these varieties have developed.

6

Contact

In the previous sections, we have examined the unagreement phenomenon in the southern Italian varieties from a syntactic perspective. In this section, we discuss the potential origins of the unagremeent configuration in southern and northern Calabrese from the perspective of language contact, given the fact that the occurrence of unagreement does not seem to be paralleled in most other Italo-Romance varieties, such as central and northern Italian dialects. Even though, to the best of our knowledge, no systematic study of the range of Italian varieties showing or disallowing unagreement is currently available, we observe from preliminary investigations that only a compact group of ItaloRomance varieties, notably those spoken in northern and southern Calabria, displays patterns of unagreement. We believe it is no accident that unagreeement is attested in the former Greek-speaking area of southern Italy and that its emergence may have been triggered by the long-lasting contact between Romance and Greek. ${ }^{16}$ Crucially, in a historical scenario of bilingualism (Fanciullo 1996, 2001), unagreement would be a morpho-syntactic hybrid configu-

16 Historical evidence shows that Greek was extensively spoken (and taught) in Calabria throughout the Middle Ages until at least the second half of the 14th century, as Francesco 
ration resulting from the transfer of a grammatical structure from one system into the other.

\subsection{Greek-Romance contact in southern Calabria}

We begin our discussion by briefly describing the sociolinguistic situation of southern Calabria. Nowadays, Greko is only spoken as a minority language in few villages of the province of Reggio Calabria (Bova (Marina), Condofuri, Gallicianò, Roghudi Nuovo). ${ }^{17}$ However, this variety used to be a dominant language in this area for many centuries (Rohlfs 1972 a.o.). Until the beginning of the 2oth century, the majority of the population in these villages was monolingual in Greko or at best bilingual in Greko-Romance. ${ }^{18}$ As a result, the deep and intense contact between Greko and the local Romance varieties brought about the emergence of many hybrid grammatical structures in both varieties (Rohlfs 1972; Katsoyannou 1995, 1997; Guardiano \& Stavrou 2014; Squillaci 2016 a.o).

In particular, southern Calabrese displays many linguistic features which have been ascribed to the Greek substratum of the area and there is ample evidence that it has transferred not only lexical material but also grammatical structures from Greek into its Romance grammar (Ledgeway 2013; Squillaci 2016; Ledgeway et al. forthcoming a, b, a.o.). Two of the most studied cases of Greek influence are (i) the lack of the present perfect and the subsequent use of the aorist tense in its place, and (ii) the dual complementiser system (viz. $c a$ and $m u$, and their allomorphs) based on a realis/irrealis distinction (Rohlfs 1972; Katsoyannou 1995, 1997; Ledgeway 2013; Roberts and Roussou 2003; Squillaci 2016 a.o.). The observations of Höhn et al. (2016) and the present paper suggest that unagreement may be an additional example for the pervasive influence of Greek.

As discussed previously, unagreement is not attested in standard Italian and, from a preliminary search into the corpus provided by ovi (Opera del Vocabolario Italiano), there seem to be no attestations of this phenomenon in Old

Petrarca in 1368 advised one of his pupils who was eager to learn Greek to go to Calabria (cf. Vasiliev 1952:718).

17 Cf. Spano (1965), Katsoyannou (2001:8-9), Martino (1980:308-313), Stamuli (2007:16-19), Remberger (2011:126-127).

18 The sharpest decline of speakers occurred from the 2oth century onwards due to several socio-economic factors (Martino 1980; Katsoyannou 1995; Stamuli 2008; Squillaci to appear). 
Italian either. By contrast, unagreement is productively employed in SMG and Calabrian Greek as well as in many Sicilian and Calabrian Romance varieties. Given the common Greek substratum of this area, and particularly given the fact that Greek has been the trigger for the development of many hybrid GreekRomance grammatical structures (cf. genitive-dative syncretism, dual complementiser, auxiliation, verbal periphrases), the hypothesis of a Greek origin of the phenomenon seems highly plausible at least in the case of unagreement in southern Calabrian.

The initially puzzling hybrid pattern-the availability of unagreement in a language with the (standard Italian) pronominal determiner structure that has previously been taken to be incompatible with unagreement-may actually provide support for the hypothesis that unagreement represents a further point of contact between Greek and Romance in southern Italy. As is well documented (see discussion in Heine \& Kuteva 2005), the emergence of hybrid structures is very frequent in contact situations. ${ }^{19}$ Indeed, when a structure is transferred from one language to the other, the resulting structure is not always a calque of the original one. Rather, it is often a new form whose features reveal the contribution of two or more systems. As shown by Heine, more generally language contact is the trigger for grammatical change. Nevertheless, languages depart form a starting point in creative ways, simultaneously employing material from whatever model language is involved as well as from their own system. Given this fundamental premise, we now consider a possible contact scenario for the development of the unagreement configuration in southern Calabrese.

Considering that the majority of the population of southern Calabria was monolingual in Greko or bilingual in Greko-Romance until the 1920s-1930s (1950s in the case of Gallicianò; cf. Squillaci 2016), this represents a sociolinguistic situation where a Romance variety would be acquired by Greko L1 speakers. Following the structural analysis in section 5, we suggest that L1 speakers of Greko transferred - among other properties - their nominal structure into the Romance dialect, when acquiring it. This would account for the development and availability of unagreement in the resulting variety. As shown in section 4 and further discussed in section 5 , the availability of further types of unagreement, notably quantificational and wh-unagreement, support the idea that there is a structural split between the locus of person, Pers, and of definiteness,

19 As for other phenomena concerning the Greek-Romance contact in southern Italy see Lekakou \& Quer (2016a, b) and Ledgeway et al. (forthcoming a, b). For discussion of the role of the vulnerability of the D-system in the development of hybrid patterns in creole languages (particularly concerning systems of specificity and definiteness marking), see Aboh (2015:171-221). 
just like in Greek. The Italian-type APCs could be the result of a surface effect that suppresses the realisation of $\mathrm{D}$ in the presence of an overt personal pronoun (see fn. 13 above). This would be consistent with the strong markedness of APCs in the southern Romance varieties discussed in section 5. As suggested there, if speakers are urged to produce an APC rather than the preferred unagreement, or if there is no $\mathrm{T}$ (or v) probe licensing the null spell-out of Pers characteristic for pro-drop, the "gap" in the paradigm could be filled by drawing on the standard Italian structure. In technical terms this could mean that the language exceptionally allows spell-out of Pers and suppresses the realisation of $\mathrm{D}$ instead (either to remain true to a general requirement to avoid co-occurrence of Pers and D, or to retain surface identity to the standard Italian pattern).

Although unagreement is — as far as we know—not displayed at all among northern and central Italian varieties and among southern Italian dialects the phenomenon is definitely patchy, even within the Greek-Romance contact areas, it is most plausible that the varieties that show unagreement nowadays have developed it through contact over time.

\subsection{Greek-Romance contact in northern Calabria}

While the interpretation of unagreement as a contact-induced linguistic feature is straightforward for southern Calabrese, and the Romance dialect of Bova Marina in particular, considering the intense long-lasting Greek-Latin/Romance coexistence until the last century, we acknowledge that the genesis of unagreement in northern Calabrese is not explained as readily.

The northern Calabria area we referred to throughout this contribution is recognized, since Lausberg's (1939) work, as a peculiar geo-linguistic continuum, known in the specialized literature as the 'Lausberg area' (Parlangèli 1971; Bigalke 1980; Caratù 1988; Fanciullo 1988; Martino 1991, a.o.), which encompasses the present-day northern Calabria and southern Basilicata. The conservative phonetic and morphological features exhibited by the Romance dialects of this area raised several questions in the past decades concerning its linguistic history, which proves to be unique within the peninsula. As Martino (1991) showed, the Romanization process beginning at the end of the 3 rd century $\mathrm{BC}$ found a region, then called Lucania, ${ }^{20}$ where among the pre-Roman

$20 \quad$ Nowadays Basilicata (previously called 'Lucania') refers to the geo-political Italian region bordering Calabria to the north. The ancient Lucania corresponds nowadays to northern 
languages ${ }^{21}$ Greek played a crucial role due to its hegemonic status, without however influencing the Italic variety spoken there, Oscan. Historical and historiographical sources, albeit often contradictory, suggest that before Latin took over, a linguistic assimilation into Greek never happened, although a long coexistence of Italic varieties and Greek is robustly attested. What did happen, though, was a profound Romanization which deeply changed the political and anthropic geography of the region. The consequent process of Latinization was boosted over the following centuries, to the detriment of the Italic varieties, and reached its acme during the 1st century BC. At that point in history, Lucania departed from the common line of events concerning southern Italy and was somehow left behind. Due to a general economic decay and demographic reduction, the area became increasingly isolated during the first four centuries AD and kept little contact with the rest of the Roman world. The isolation severely slowed down the linguistic evolution with respect to the Romance development elsewhere (Wartburg 1980) and arguably gave rise to the numerous archaic features that the modern dialects still display. After the Byzantine conquest in the 6th century the region became an eparchy, but its condition of seclusion did not change. It actually became even more extreme in the 8th century, when the marginal cultural role of the area and the linguistic influence of Byzantine Greek further affected the evolution of Latin into Romance, which could never absorb the linguistic innovations occurring in the rest of the Latin/Romance-speaking world. Therefore, the notorious conservative linguistic character of the 'Lausberg Area' has to be connected to the geographical, social, religious and cultural conditions of Lucania between the 3 rd and the 6th centuries, which reveal an impoverished and divided territory that could not put up the same resistance to the Greek influence as it did six centuries before, at the time of the conquest of Rome.

The medieval pre-Norman northern Calabria was extensively influenced by Byzantine culture (Guillou 1965 a.o.). The consequent diffusion of Greek had its apogee in the 11th century with the establishment of the Theme of Lucania. According to Falkenhausen (1978), at the same time the area was reached by the migration of population from Sicily and southern Calabria. If we zoom into northwestern Calabria, we see that the origin of many mountainous villages (including Verbicaro, the source of our northern Calabrian data) is due to the foundation of several Byzantine monasteries across the area encompassing

Calabria and a great portion of the Italian region of Basilicata. The present-day central and southern Calabria corresponded to the area referred to as Bruttium.

21 See Silvestri (1998) and Rix (2003). 
the present-day northern Calabria and southern Basilicata, which was officially defined as the Eparchy of Mercurion ${ }^{22}$ (Borsari 1963; Guillou 1972). In particular, in northwestern Calabria the presence of Byzantine monks is attested over a period of time between the 8th and the 13th century (Mercati 1937; Cappelli 1963; Campagna 1988), thus enduring for two more centuries after the establishment of the Normans in Calabria and Basilicata (11th century; van Houts 200o) and arguably forming ethnic islands united by one language and one cultural tradition, which was represented by the monasteries (the most important founding dates from the 12th century). Even though so far no linguistic evidence has been retrieved as robust as the traces concerning the GreekRomance contact in southern Calabria, it seems plausible that the historical influence of a vivid Byzantine Greek monasticism in northern Calabria (and southern Basilicata) may have affected the culture of several villages in many aspects, including language. As Caracausi (1986) points out, the Greek linguistic influence of the monks did not overcome the uninterrupted Latin/Romance substratum. However, it integrated and coexisted with it. Unfortunately, the shortage of historical written sources for the relevant varieties highly limits the possibility of detailed diachronic reconstruction on the development of unagreement in northern Calabrian. However, the hypothesis that the systematic availability of unagreement in northern Calabrese is the result of the contact situation in the Byzantine era seems well worth pursuing.

\section{Conclusion}

To conclude, in this paper we have discussed unagreement data from southern Italian Greek and Romance varieties. While the Calabrian Greek variety Greko essentially patterns with SMG as far as unagreement and the structure of APCS is concerned, the Italo-Romance dialects display a hybrid pattern. Northern and southern Calabrese clearly show the unagreement phenomenon, but their APCs lack the definite article, just like APCs in standard Italian. This poses a problem for accounts which link the availability of unagreement to the mandatory use of definite articles in APCs.

We have proposed to extend Höhn's (2016) unagreement account to the Italo-Romance varieties. The core hypothesis that the structural correlate of unagreement is the encoding of person features separately from definiteness is

22 The geographical boundaries as well as the origin of the name of this monastic area are still objects of discussions. We refer to Roma (2012) for an outline of different hypotheses. 
supported by the availability of further types of unagreement in these dialects (quantificational, wh- and relative clause unagreement), which also suggest a decoupling of person features from the D position. If this is on the right track, the stability of the hybrid pattern of pronominal determiner-type APCs and unagreement may suggest a shift in perspective regarding the acquisition of the relevant nominal structures. Rather than specific APC patterns triggering the availability of unagreement, it may be that the availability of unagreement leads learners to posit a nominal structure with independent person features, and the observable APC patterns in languages like Greek follow from that structure. This would allow learners of the southern Italian varieties to acquire the "Greek-type" nominal structure that licenses the various unagreement phenomena, while the sociolinguistic influence of standard Italian might play a role in preventing or blocking the occurrence of the overt article in APCS, possibly by supporting an endemic morphophonological restriction against the co-occurrence of overt realisations of Pers and D. These speculations call for extensive further research into the actual usage patterns of APCs and unagreement in order to achieve an understanding of their potential role in the acquisition of nominal structure.

Finally, we have addressed the role of language contact between Greek and Romance varieties in the relevant areas as the likely source of the unexpected patterns of unagreement. For southern Calabrese the influence of Greek is widely accepted, so the hypothesis that the Greek nominal structure was adopted into the Romance variety is very plausible. For the occurrence of unagreement in northern Calabrese we tentatively suggest the possibility of an influence from Greek-Romance contact in the Byzantine era.

\section{References}

Abney, Steven. 1987. The English noun phrase in its sentential aspect. PhD dissertation: MIT.

Aboh, Enoch. 2015. The Emergence of Hybrid Grammars. Cambridge: Cambridge University Press.

Ackema, Peter, and Ad Neeleman. 2013. Subset controllers in agreement relations. Morphology 23.291-323.

Arnaudova, Olga. 1998. Demonstratives and the structure of the Bulgarian DP. Trondheim Working Papers in Linguistics 31.1-12.

Bigalke, Rainer. 1980. Dizionario dialettale della Basilicata. Heidelberg: Winter.

Borsari, Silvano. 1963. Il monachesimo bizantino nella Sicilia e nell'talia meridionale prenormanne. Napoli: Istituto Italiano per gli Studi Storici. 
Caink, Andrew. 2002. In favor of a 'clitic cluster' in the Bulgarian and Macedonian DP. Papers from the 3rd Conference on Formal Approaches to South Slavic and Balkan Languages (University of Trondheim Working Papers in Linguistics 34), ed. by M. Dimitrova Vulchanova, I. Krapova and L. Hellan, 170-182. Trondheim: University of Trondheim.

Cappelli, Biagio. 1963. Il monachesimo basiliano ai confini calabro-lucani. Napoli: Fausto Fiorentino Editore.

Caracausi, Girolamo. 1986. Lingue in contatto nell'estremo Mezzogiorno d'Italia: influssi e conflittifonetici. Palermo: Centro di studi filologici e linguistici siciliani.

Caratù, Pasquale. 1988. La Lucania Meridionale. Lexicon der Romanistischen Linguistik (LRL), IV, ed. By G. Holtus, M. Metzeltin and C. Schmitt, 688-694. Tübingen: Max Niemeyer Verlag.

Choi, Jaehoon. 2013. Pro-drop in pronoun-noun constructions. NE LS 42: Proceedings of the 42 nd Annual Meeting of the North East Linguistic Society, ed. by Stefan Keine and Shayne Sloggett, 119-128. Amherst: GLSA.

Choi, Jaehoon. 2014. Pronoun-noun constructions and the Syntax of DP. PhD dissertation, University of Arizona.

CNR, Opera del Vocabolario Italiano, http://www.ovi.cnr.it/index.php/it/

Embick, David. 2010. Localism versus globalism in morphology and phonology. Cambridge (MA): MIT Press.

von Falkenhausen, Vera. 1978. La denominazione bizantina nell'Italia meridionale dal IX all'XI secolo. Bari: Ecumenica.

Fanciullo, Franco. 1988. Lucania. Lexicon der Romanistischen Linguistik (LRL), IV, ed. by G. Holtus, M. Metzeltin and C. Schmitt, 669-688. Tübingen: Max Niemeyer Verlag. Franciullo, Franco. 1996. Per una storia linguistica dell'Italia meridionale. Pisa: E Ts.

Fanciullo, Franco. 2001. On the origins of Greek in southern Italy. In Proceedings of the ist International Conference of Modern Greek Dialects and Linguistic Theory, ed. by A. Ralli, B. Joseph and M. Janse, $67-78$. Patras: University of Patras.

Guardiano, Cristina and Melita Stavrou. 2014. Greek and Romance in Southern Italy. History and contact in nominal structures. L'Italia Dialettale LXXV.121-148.

Guillou, André. 1965. La Lucanie byzantine. Étude de géographie historique. Byzantion 35, I.119-149.

Guillou, André. 1972. Spiritualità e società religiosa greca nell'Italia Meridionale e la Sicilia. Bari: Istituto Superiore di Teologia Ecumenica "S. Nicola".

Halle, Morris, and Alec Marantz. 1993. Distributed morphology and the pieces of inflection. The view from Building 20, ed. by Kenneth Hale and Samuel Jay Keyser, 111-176. Cambridge: Mit Press.

van Houts, Elisabeth (ed.). 20oo. The Normans in Europe. Manchester: Manchester Medieval Sources.

Höhn, Georg F.K. 2014a. The semantics of adnominal pronouns and unagreement. 
Complex Visibles Out There. Proceedings of the Olomouc Linguistics Colloquium 2014: Language Use and Linguistic Structure, ed. by Ludmila Veselovská and Markéta Janebová, 175-191. Olomouc: Palacký University.

Höhn, Georg F.K. 2014b. Contextually conditioned allomorphy and the Basque locative. Spelling out the Basque extended nominal projection. ConSOLE XXI: Proceedings of the 21st Conference of the Student Organization of Linguistics in Europe (8-10 January 2013, Potsdam), ed. by Martin Kohlberger, Kate Bellamy and Eleanor Dutton, 146-170. Leiden: Leiden University Centre for Linguistics.

Höhn, Georg F.K. 2016. Unagreement is an illusion. Apparent person mismatches and nominal structure. Natural Language and Linguistic Theory 32.543-592.

Höhn, Georg F.K. 2017. Non-possessive person in the nominal domain. PhD dissertation: University of Cambridge.

Höhn, Georg F.K., Giuseppina Silvestri and Maria Olimpia Squillaci. 2o16. Unagreement between Italian and Southern Italian Dialects. Rivista di Grammatica Generativa 38.137-147.

Hurtado, Alfredo. 1985. The unagreement hypothesis. Selected papers from the Thirteenth Linguistic Symposium on Romance Languages, ed. by Larry King and Catherine Maley, 187-211. Amsterdam: John Benjamins.

Katsoyannou, Marianne. 1995. Le parler gréco de Gallicianò (Italie): Description d'une langue en voie de disparition. Doctoral thesis, Université Paris VII.

Katsoyannou, Marianna. 1997. Interventi simbiotici tra greco e romanzo nell'area linguistica calabrese. Atti del secondo incontro internazionale di lingua greca, ed. by E. Banfi, 513-531. Trento: Università degli Studi, Dip. di Scienze filologiche e storiche.

Katsoyannou, Marianne. 2001. Le parler grec de Calabre. Lalies 21.7-86.

Ledgeway, Adam. 2013. Greek Disguised as Romance? The Case of Southern Italy. Pro-

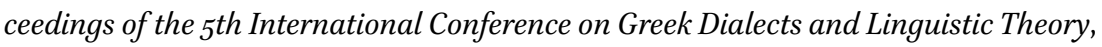
ed. by Mark Janse, Brian D. Joseph, Angela Ralli and Metin Bağriacik, 184-228. Laboratory of Modern Greek Dialects, University of Patras.

Ledgeway, Adam, Norma Schifano and Giuseppina Silvestri. Forthcoming a. Variazione nella codifica degli argomenti verbali nelle varietà romanze e greche della Calabria meridionale: 'dativo greco' e marca differenziale dell'oggetto diretto. Atti del v Convegno Internazionale di Dialettologia-Progetto A.L.Ba., ed. by P. Del Puente. Rionero in Vulture: Calice Editore.

Ledgeway, Adam, Norma Schifano and Giuseppina Silvestri. Forthcoming b. Variazione nella codifica degli argomenti verbali nelle varietà romanze e greche della Calabria meridionale: i costrutti causativi. Atti del v Convegno Internazionale di Dialettologia-Progetto A.L.Ba., ed. by P. Del Puente. Rionero in Vulture: Calice Editore.

Lekakou, Marika and Josep Quer, 2016a. Aspect in the service of mood: the morphosyntax of subjunctive in Griko. Proceedings of the international Conference on Modern 
Greek Dialects and Linguistic Theory 6.1.79-92. Available at http://electra.lis.upatras .gr/index.php/mgdlt/article/view/2675.

Lekakou, Marika and Josep Quer, 2016b. Subjunctive mood in Griko: A micro-comparative approach. Lingua $174.65^{-85}$.

Longobardi, Giuseppe. 1994. Reference and proper names: a theory of N-movement in syntax and logical form. Linguistic Inquiry 25.609-665.

Longobardi, Giuseppe. 2008. Reference to individuals, person, and the variety of mapping parameters. Essays on Nominal Determination: from morphology to discourse management, ed. by A. Klinge and H. Müller, 189-211. Amsterdam: John Benjamins.

Martino, Paolo. 198o. 'L'isola grecanica dell'Aspromonte; aspetti sociolinguistici'. I dialetti e le lingue delle minoranze di fronte all'italiano: Atti del XI Congresso Internazionale di Studi, ed. by F.A. Leoni (ed), 305-341. Rome: Bulzoni.

Martino, Paolo. 1991. L' “Area Lausberg”. Isolamento e arcaicità. Roma: Dipartimento di Studi Antropologici dell'Università di Roma "La Sapienza".

Mercati, Giovanni. 1937. San Mercurio e il Mercurion. Archivio Storico per la Calabria e la Lucania 7, III-IV, 295-296 (129-130).

Nevins, Andrew. 2007. The representation of third person and its consequences for person-case effects. Natural Language and Linguistic Theory 25.273-313.

Nevins, Andrew. 2011. Multiple agree with clitics: Person complementarity vs. omnivorous number. Natural Language and Linguistic Theory 29.939-971.

Ordóñez, Francisco, and Esthela Treviño. 1999. Left dislocated subjects and the prodrop parameter: A case study of Spanish. Lingua 107.39-68.

Panagiotidis, Phoevos. 2002. Pronouns, Clitics and Empty Nouns. Amsterdam: John Benjamins.

Panagiotidis, Phoevos. 2011. Categorial features and categorizers. The Linguistic Review $28.365-386$.

Panagiotidis, Phoevos. 2015. Categorial features. A generative theory of word class categories. Cambridge: Cambridge University Press.

Parlangèli, Oronzo. 1971. Note di storia linguistica italiana: a proposito dell'area Lausberg. Sprache und Geschichte. Festschrift für Harri Meier zum 65. Geburtstag, ed. by Eugenio Coseriu and Wolf-Dieter Stempel, 353-372. München: Fink.

Postal, Paul. 1969. On so-called "pronouns" in English. Modern studies in English: Readings in Transformational Grammar, ed. by David A. Reibel and Sanford A. Schane, 201-226. Englewood Cliffs: Prentice Hall.

Rix, Helmut. 2003. Ausgliederung und Aufgliederung der italischen Sprachen. Languages in Prehistoric Europe (Indogermanische Bibliothek3), ed. by A. Bammesberger and T. Vennemann, 147-172. Heidelberg: Winter.

Roma, Giuseppe. 2012. Rilettura di un abusato tópos: il Mercurion. Medioevo letto, scavato, rivalutato. Studi in onore di Paolo Peduto, ed. by Chiara Fiorillo and Chiara Lambert, 125-131. Firenze: Editrice del Giglio. 
Rohlfs, Gerhard. 1972. Nuovi scavi linguistici nell'antica Magna Grecia. Palermo: Istituto Siciliano di Studi Bizantini e Neoellenici.

Silvestri, Domenico. 1998. The Italic languages. The Indo-European Languages, ed. by A. Giacalone Ramat and P. Ramat, 322-344. London: Routledge.

Silvestri, Giuseppina. 2013. The nature of Genitive Case. PhD Dissertation: University of Pisa.

Sommerstein, Alan H. 1972. On the so-called definite article in English. Linguistic Inquiry 3.197-209.

Squillaci, Maria Olimpia. 2016. When Greek meets Romance: A Morphosyntactic Investigation of Language Contact in Aspromonte. PhD Dissertation: University of Cambridge.

Squillaci, Maria Olimpia. To appear. When a language becomes old. The case of Calabrian Greek. Selected papers from the XV International Conference on Minority Languages. Belgrade: University of Belgrade.

Stamuli, Maria Francesca. 2008. Morte di lingua e variazione lessicale nel greco di Calabria. Tre profili dalla bovesia. PhD dissertation: Università degli Studi di Napoli 'Federico II'.

Vasiliev, Alexander. 1952. History of the Byzantine Empire (324-1453). Madison: The University of Wisconsin Press.

Villa-García, Julio. 2010. To agree or not to agree: Beyond quintessentially syntactic agreement in Spanish. Romance Linguistics 2009: Selected papers from the 3oth Linguistics Symposium on Romance Languages (LSRL), Tucson, Arizona, March 2009, ed. by Sonia Colina, Antxon Olarrea and Ana Maria Carvalho, 249-266. Amsterdam: John Benjamins.

von Wartburg, Walther. 1980. La frammentazione linguistica della Romània. Roma: Salerno Editrice. 